\title{
Prevalence and Severity of Current Human-Elephant Conflicts in Amboseli Ecosystem, Kenya: Insights from the Field and Key Informants
}

\author{
Moses Makonjio Okello ${ }^{*}$, Stephen J. Njumbi ${ }^{2}$, John Warui Kiringe ${ }^{1}$, James Isiiche ${ }^{2}$ \\ ${ }^{1}$ SFS Center for Wildlife Management Studies, Nairobi, Kenya \\ ${ }^{2}$ International Fund for Animal Welfare (IFAW), Nairobi, Kenya \\ Email: ${ }^{*}$ mokello@fieldstudies.org, mokello33@gmail.com
}

Received 1 June 2014; revised 1 July 2014; accepted 10 July 2014

Copyright (C) 2014 by authors and Scientific Research Publishing Inc.

This work is licensed under the Creative Commons Attribution International License (CC BY). http://creativecommons.org/licenses/by/4.0/

(c) (i) Open Access

\section{Abstract}

Few animals elicit such drastically different human emotions, so do elephants. Elephants capture the affection of people but also inspire animosity and fear at the same time. This is because there are conflicts with people over space, critical resources, costs of damages and general insecurity to people. This paper examined field evidence and interviewed expert key informants on current intensity and frequency of human-elephants in Amboseli Ecosystem. According to them, generally, the most prevalent (score of 1 lowest to 10 highest) threats to elephants were competition for critical resources $(6.32 \pm 0.44)$ followed by blocking of migration $(6.24 \pm 0.46)$, harassment of elephants $(4.83 \pm 0.75)$, poaching $(4.57 \pm 0.37)$, and retaliatory killings $(3.78 \pm 0.31)$. For threats that elephants pose to people, the most prevalent one was crop raiding $(6.95 \pm 0.26)$ followed by environmental degradation $(6.71 \pm 0.46)$, general insecurity to people $(5.76 \pm 0.65)$, property destruction $(5.16 \pm 0.41)$, injury and death to livestock $(3.78 \pm 0.37)$, and injury and death to people $(2.71 \pm 0.27)$. For the severity of the threats, the highest score was given to crop raiding whose average score was $7.90 \pm 0.24$ followed by environmental destruction and degradation (6.89 \pm 0.43$)$, injury and death to people $(6.72 \pm 0.44)$, injury and death to livestock $(6.36 \pm 0.50)$, property destruction $(5.78 \pm 0.49)$, general insecurity to people $(5.62 \pm 0.64)$. Severity levels followed the same trend or varied slightly. These drivers of human-elephant conflicts need to be addressed decisively to protect both people and elephants. There is a need to ensure local people's benefit from elephants through ecotourism investments such as wildlife sanctuaries, leasing critical space for elephants' dispersal on acceptable terms, through appropriate compensation schemes for elephant costs, and supporting local community wildlife rangers to prevent conflicts.

*Corresponding author.

How to cite this paper: Okello, M.M., Njumbi, S.J., Kiringe, J.W. and Isiiche, J. (2014) Prevalence and Severity of Current Human-Elephant Conflicts in Amboseli Ecosystem, Kenya: Insights from the Field and Key Informants. Natural Resources, 5, 462-477. http://dx.doi.org/10.4236/nr.2014.59043 


\section{Keywords}

\section{Amboseli Ecosystem, Elephants, Human-Elephant Conflicts, Kenya, Threats Facing Elephants}

\section{Introduction}

Few wild animals elicit drastically different human emotions, so do elephants. They capture the imagination and unswerving affection of people worldwide, but also inspire animosity and fear among those sharing their land with these mega-herbivores [1] [2]. Two factors have a large effect on determining the numbers and distribution of elephants in Kenya, and elsewhere in Africa. These are poaching or hunting, and competition for conversion of land by people [3]-[7]. Therefore there has been a steady decrease in elephant habitats over many decades throughout Africa wherever human populations have increased [8]. Thus, there is a linear, negative relationship between human population size and elephant density. However, coexistence is possible at low human densities, while loss of habitat occurs at a critical threshold level of roughly 15 people per $\mathrm{km}^{2}$ [8].

Apart from the widespread habitat loss that is facing elephant populations across the entire African continent, illegal hunting can eliminate populations, even when human land use would otherwise allow coexistence. For instance, elephants were effectively eradicated from large areas of the continent during the intensive ivory trade in the 18th Century and particularly late 19th Century, when ivory exploitation was often combined with trade in human slaves [5]. However, the mid-20th Century was characterized by recovery of elephant populations from this massive depletion, erupting into woodland habitats that had grown up in the absence of elephants. Thereafter, hunting for the ivory trade began increasing again during the 1970s and this was another factor that caused the population increase apparent within protected areas [9]-[11] as elephants avoided the danger posed by humans, and instead, sought the safety of protected areas [12]-[16].

Further, field reports from across Africa report local community antipathy to elephants beyond that expressed for any other wildlife species [5] [17]. Communities surrounding forest reserves and conservation areas engage in small-scale subsistence and cash-crop farming. Those farms close to the boundary are vulnerable to elephant crop damage, which is most intense during the food crop-harvesting season, but also occurs to a lesser extent throughout the year [18]. Elephants jeopardize communities' food security and livelihoods and communities' attitudes towards elephants are consequently and consistently negative. Resolving this conflict has become critical to the improvement of the livelihoods of rural communities co-existing with elephants and the conservation of the elephant populations [2].

The resolution of direct conflict between humans and elephants in Africa has become a serious local sociopolitical issue in recent years, and a continental conservation problem [18] [19]. Many studies have therefore shown that elephant causes diverse damage types including crop depredation, property damage and even threat to human life. A study [19] indicated that about eighty percents (80\%) of the African elephant's range lies outside formally protected areas, and inadequate management of the conflicts with humans is frequently a pre-cursor to further decline in the numbers and distribution of elephants [5].

Land use changes have been shown to have significant effects on wildlife species [3]. Sixty three percents (63\%) of Kenya's protected areas are situated in savannas, which are characterized by spatio-temporal variation in their environment. Consequently, most of their wildlife (nearly 75\%) spend a lot of their time in adjoining landscapes. Thus, successful conservation of wildlife in Kenya including elephants has to address the changes that are taking place in areas outside the existing network of protected areas [3].

For decades, the relationship between the Maasai and wildlife found on their land has been described as "harmonious" and "tolerant." However, this situation has changed and intense conflicts and competition for space and resources like water and pasture characterize Maasai land. Due to decline of suitable elephant habitat quality in Amboseli over the years [3], elephants frequently use areas outside the park leading to an escalation of human-elephant conflicts, with 489 elephant damage incidences recorded between June 1996 and July 1997. Therefore degradation of elephant habitats outside Amboseli N. Park due to inappropriate human activities or as a result of climate change will give rise to higher prevalence of conflicts between elephants and local communities [20] [21].

Susceptibility of farms to crop raiding by African elephants in Kenya was investigated in a study around Maasai Mara [18]. The study noted that crop raiding by elephants reduced their tolerance by locals and impeded 
conservation efforts. He showed that within conflict zones, crop raiding was not distributed equally amongst farms due to variation in local physical or geographical factors, or in farmers' efforts to defend their fields. The application of enhanced early warning and guarding effort in previously raided farms reduced incidents of crop raiding by $89.6 \%$ over 2 years in comparison with a control group of farms. They therefore concluded that early detection of elephants approaching fields increased guarding effort, and the use of active deterrents could form the basis of an effective mitigation strategy regardless of location and the physical attributes of a farm [18].

In another study [22], elephants engaged in crop raiding even though the crops raided were not consumed. Further, the number of elephant raids on crops increased with the size of the farm and with the proximity to the park boundary, and the elephants mostly targeted mature crops. Therefore owners of farms around protected areas should be supported to use the available deterrent methods such as chili fences to prevent more damages [22]. Also, farmers should be advised to plant trees that are undesirable to the elephants close to the boundary to act as buffer. A buffer zone of at least $100 \mathrm{~m}$ from a protected area boundary should be considered. There can be a large pool of elephant crop raiders but this is affected by the availability of palatable crops in areas of conflict, and the link between crop-raiding and recruitment of habitual raiders from this pool of occasional raiders [23]. Consequently, an ethical management strategy (other than shooting raiders) that uses remote monitoring of raiders as an early warning system for crop protection is more appropriate [23].

The performance of electric fences as elephant barriers in Amboseli Kenya has been documented [24]. They assessed the performance of Namelok and Kimana fences in reducing human-elephant conflict by comparing the frequency of crop-raiding by elephants and the perceptions of farmers on the effect of the fences in reducing elephant crop-raiding within fenced and adjacent unfenced farmlands. Namelok fence was not broken by elephants whereas Kimana fence was broken several times probably because it borders Kimana Sanctuary which provided cover where elephants could retreat after crop-raiding. The mere presence of an electric current did not minimize fence breakage by elephants. Elephants entered fenced areas more frequently when the fence wires were broken than that when wires were intact. Their results suggested that location of fences in relation to landscape factors, maintenance of effective non-electrified fences and proximity of fences to areas of high elephant concentration were significant determinants of fence performance in mitigating elephant crop-raiding. But electric fences do need other strategies to reduce human-elephant conflicts [25].

From the foregoing synopsis of various aspects of the African elephant-human interactions, it is important to frequently assess and monitor the conflict types, the prevalence and severity of threats to humans and elephants' pose to each other. It is also critical to identify drivers of the conflicts and identify hotspots where they are more prevalent so that appropriate mitigation strategies borrowed from good practices reported in literature can be applied. This study sought to examine these aspects within the Amboseli ecosystem. In this regard, this study attempts to provide more insights on human-elephant conflicts in one of the critical elephant conservations areas in the country. This will enable the Kenya Wildlife Service (KWS), conservation non-governmental organizations and local communities involved in wildlife conservation to make informed decisions on the best practices to enhance elephant conservation and their co-existence with the surrounding local communities.

\section{Objectives}

The overall objective of this research was to establish the expert opinions and field evidence of human-elephant conflicts take in Amboseli Ecosystem, and the current prevalence and intensity of such conflict types. The specific objectives were to:

1) Identify types of threats to elephants, their prevalence and severity based on long-term data documented by the KWS Problem animal Control (PAC) units of KWS;

2) Evaluate threat types to elephants, their prevalence and severity based on perceptions of key informants and wildlife experts and researchers in Amboseli;

3) Identify resources competed for between humans and elephants that are at the center of the conflicts between elephants and locals;

4) Make recommendations for effective and sustainable management and mitigation of threats against elephants in the Amboseli region.

\section{Methodology}

This work was done in Amboseli area which is over $5000 \mathrm{~km}^{2}$ with surrounding Maasai group ranches and pri- 
vately owned lands (Figure 1). It involved interviews with key informants and local community drawn widely from the area. Doing a study on the threats to elephants and what threats they pose to communities living with them is a complex and multidimensional exercise [26]. It cuts across ecology, climate change, human interactions [27], and institutional policies. This work was done between January and June 2013.

Examination of field data was collected by the Kenya Wildlife Service (KWS) Problem Animal Control (PAC) units in Rombo, Oloitoktok and Amboseli N. Park. Field data was obtained from daily records of actual incidences that involve all kind of conflicts between elephants and people between 2011 and 2012 in three PAC locations in Rombo, Oloitoktok and Amboseli N. Park. These were copied and information on the kind of conflict, date, and number of elephants involved (as a measure of severity of the conflicts) taken.

Further, a total of 78 people from KWS, local leadership (political, administrative, and group ranch leadership of the local community) and selected people knowledgeable and involved in elephant conservation in KWS, research and conservation organizations and who have been working in the ecosystem were interviewed. Some of the key issues that were addressed during the interviews and discussions with key informants, researchers and experts in elephant matters in the Amboseli included types of threats that elephants face from people, and those people face from elephants.

Respondents were requested to score on an ordinal scale of 1 (lowest) to 10 highest for both the prevalence and severity of the identified threats. We also established the seasons and times of the year when conflicts were high, critical resources competed for by humans and elephants, drivers of human-elephant conflicts, locations (hotspots) where these conflicts mostly occurred, and places (hotspots) where these conflicts are most prevalent. The kind of mitigation strategies respondents thought would work in containing the escalating human-elephant conflicts in the ecosystem were also examined. We used a combination of PRA methods from focused group discussions to discussion with key informants and local community guided by an administered questionnaire.

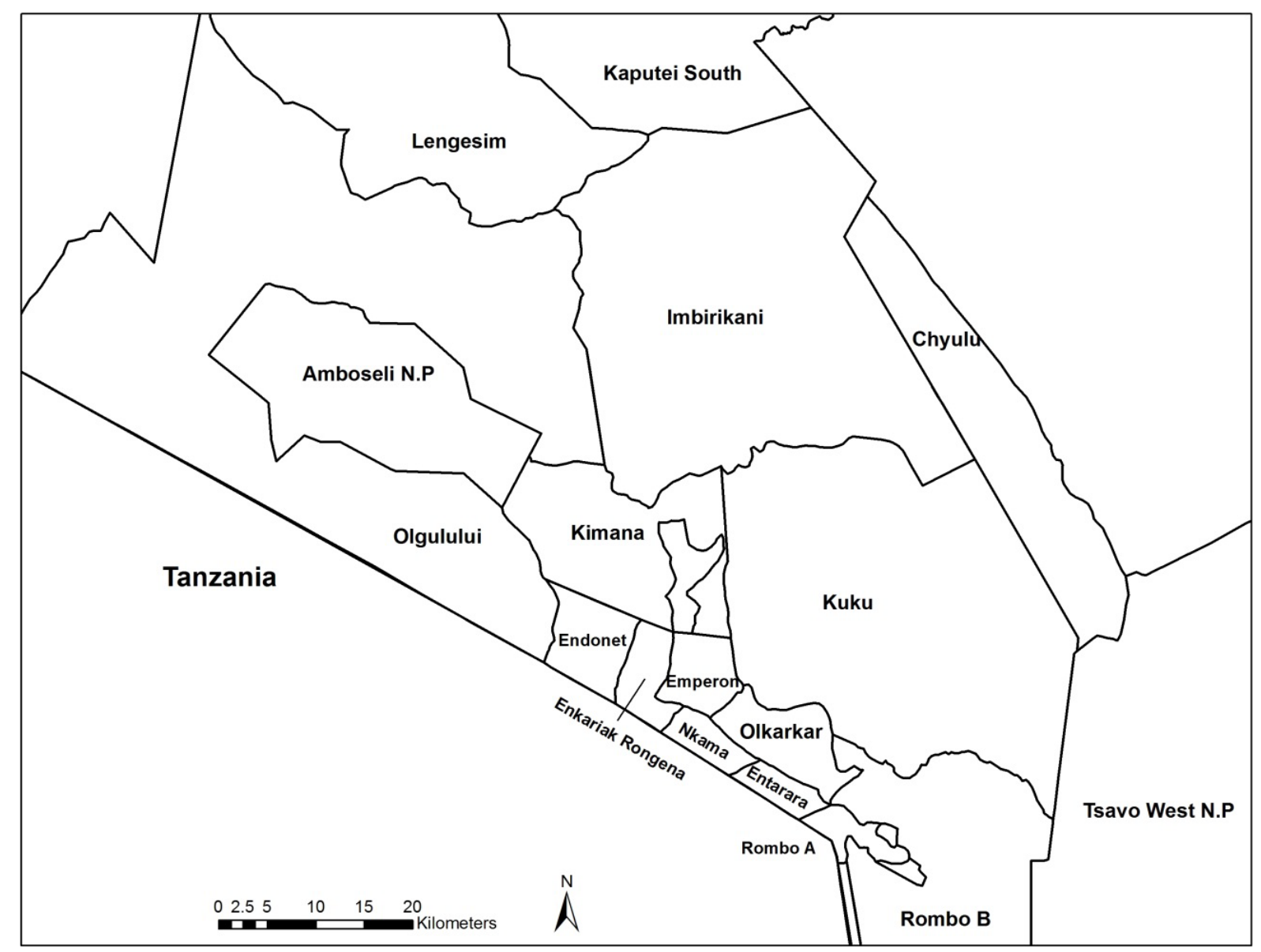

Figure 1. Amboseli and surrounding private and communal Maasai group ranches in Southern Kenya. 
Using the data collected, explorative, descriptive and inferential techniques were used to establish frequencies and means of responses (and their percentage) to the issues that were evaluated during the study. Where appropriate, Chi-square goodness of fit test used to establish equality of frequencies of responses. Chi-square cross tabulations were also used to establish if there was a relationship between interviewee attributes and their responses [28]. One way Anova tests were used to establish any statistical differences between average scores for prevalence and severity of threats to elephants [28].

\section{Results}

\subsection{Human-Elephant Conflicts from Field Recorded Incidences}

A total of 651 cases involving 3092 elephants were observed in the KWS incidences report records. From the records, four (4) key types of conflict-related activities involving elephants were noted (Table 1): elephants near farms which would potentially lead to crop depredation , actual crop damage by elephants, threat to human security, destruction of property (non-crop, non-livestock), and visibly sick elephants that could be a threat to the safety of humans . Majority of the incidences $(69.4 \%$ of the cases) involved elephants reported near farms impending invasion, followed by crop damage (22.27\%), threat to human security $(7.22 \%)$ and destruction of property $(0.31 \%)$. The number of elephants involved in these key conflict-related issues (Table 1 ) showed a similar trend, with the largest number of elephants involved in farm invasion followed by crop damage, threat to human security and destruction of property. There were two elephants reported to have died in the KWS records in the Rombo area which is close to the Tanzania border, and both had their tusks missing.

The highest incidences of human-elephant conflicts (67.90\%) were recorded in the Oloitoktok KWS office, and were attributed to $76.33 \%$ of the elephants involved in such conflicts (Table 2). These were followed by 24.88\% of incidences reported at the Amboseli National Park headquarters involving 23.58\% of elephants. Rombo area had the least recorded incidences (7.22\%) comprising very few recorded elephant numbers. This could be a serious underestimate of human-elephant conflicts since the KWS staffdid not always indicate the number of elephants involved for each incidence reported to them by the locals. The action taken by KWS rangers in PAC included; scaring away elephants, monitoring their movements and retrieving tusks form dead elephants. Sometimes they did not take any action if they were on other errands or resources were limiting (Table 2). The leading elephant issues recorded in the Oloitoktok KWS incidence reports were farm invasion which led to crop damage and threat to human security. In the Rombo reports, the leading conflict type was threat to human security followed by crop damage and lastly elephant mortality. For incidences recorded in Amboseli N. Park records, the leading conflict type was threat to farm invasion (followed by crop damage), threat to human security and property damage in that order (Table 2).

In terms of areas where human-elephant conflicts incidents were common (i.e. conflict hotspots), the records in the three KWS offices, showed areas of high prevalence (based on number of cases reported) and severity (based on the number of elephants reported to have been involved). For Oloitoktok records, the leading threats were on farm invasion, followed by crop damage, insecurity to humans and lastly destruction of property. In

Table 1. A summary of prevalence and severity of recent human-elephant conflicts in Amboseli Area from HEC records by KWS Officers between 2011 and 2012.

\begin{tabular}{cccc}
\hline Conflict & Types of conflict (frequency) & Frequency of incidences (\%) & $\begin{array}{c}\text { Number of elephants involved, } \\
\text { some repeated (\%) }\end{array}$ \\
\hline 1 & Threat of farm invasion & $452(69.43)$ & $2053(66.40)$ \\
2 & Crop damage & $145(22.27)$ & $941(30.43)$ \\
3 & Threat to human security & $47(7.22)$ & $83(2.68)$ \\
4 & Destruction of property & $2(0.31)$ & $3(0.32)$ \\
5 & Sick animal & $3(0.46)$ & $2(0.06)$ \\
\hline
\end{tabular}


Table 2. A summary of recent human-elephant conflicts types, frequency and actions taken in Amboseli Area from HEC records by KWS Officers between 2011 and 2012.

\begin{tabular}{|c|c|c|c|}
\hline Location of records & $\begin{array}{l}\text { Types of conflict } \\
\text { (frequency) }\end{array}$ & $\begin{array}{l}\text { Number of elephant } \\
\text { (some repeat) }\end{array}$ & $\begin{array}{l}\text { Actions taken by KWS } \\
\text { control unit }\end{array}$ \\
\hline \multirow{5}{*}{$\begin{array}{l}\text { Oloitoktok Problem Animal } \\
\text { Control (PAC) Office }\end{array}$} & Threat of farm invasion (304) & 1441 (21 cases missing numbers) & \multirow{5}{*}{$\begin{array}{l}\text { - Driven away from source of } \\
\text { conflicts } \\
\text { - Sometimes the offending } \\
\text { elephant disappeared before } \\
\text { the PAC unit arrived } \\
\text { - Monitored until away from } \\
\text { human dwelling or farms }\end{array}$} \\
\hline & Crop damage (118) & 829 (24 cases missing numbers) & \\
\hline & Threat to human security (16) & 77 & \\
\hline & Destruction of property (1) & 10 & \\
\hline & Sick animal (3) & 3 & \\
\hline Sub total & $442(67.90 \%)$ & $2360(76.33 \%)$ & \multirow{5}{*}{$\begin{array}{l}\text { - Tusks retrieved by KWS } \\
\text { - Driven away from source } \\
\text { of conflict } \\
\text { - Nothing done especially } \\
\text { where KWS officers are on } \\
\text { other errands! } \\
\text { - Animal not sighted }\end{array}$} \\
\hline \multirow{3}{*}{ Rombo KWS PAC Offices } & Threats to humans security (29) & $\begin{array}{c}1 \text { (all cases except one missing } \\
\text { numbers) }\end{array}$ & \\
\hline & Crop damage (16) & (all cases missing numbers) & \\
\hline & $\begin{array}{l}\text { Elephants found dead } \\
\text { cause unknown (2) }\end{array}$ & 2 (1 without tusks) & \\
\hline Sub total & $47(7.22 \%)$ & $3(0.01 \%)$ & \\
\hline \multirow{4}{*}{$\begin{array}{c}\text { Amboseli National Park } \\
\text { Headquarters Offices }\end{array}$} & Threat to farm invasion (148) & 612 (one case missing number) & \multirow{6}{*}{$\begin{array}{l}\text { - Driven away from source of } \\
\text { conflict } \\
\text { - Animal not sighted }\end{array}$} \\
\hline & Crop damage (11) & 112 & \\
\hline & Threat to human security (2) & 5 & \\
\hline & Property destruction (1) & Missing number & \\
\hline Sub total & $162(24.88 \%)$ & $729(23.58 \%)$ & \\
\hline Grand Total & 651 & 3092 & \\
\hline
\end{tabular}

terms of prevalence records at the Oloitoktok office, the leading hotspots in decreasing order in terms of farm invasion were; Sompet, Bondeni, Impironi, Sayianga, InkariakRongena, Elerai, Noomanayiat, Entonet, Kimana, Enkii and Isinet; while for the number of elephants involved (in decreasing order) were; Sompet, Empiron, Bondeni, Sayianga, InkariakRongena, Entonet, Elerai, Noomanayiat, Kimana and Enkii. For crop destruction prevalence in Oloitoktok offices, the leading hotspots were (in decreasing order); Sompet, Bondeni, Inkariak Rongena, Empironi, and Noomanayiat; while for the number of elephants involved (in decreasing order) was; Sompet, Bondeni, InkariakRongena, Empironi, and Entonet. For threat to human security both for prevalence and severity in Oloitoktok office, the leading hotspots were (in decreasing order) Elerai, Kimana and Nomanayiat. Two cases of sick animal monitoring were done at Emboonjo and Mbirikani. There was only one incidence of property destruction, and at Elerai.

For the Rombo records, the leading threat associated with elephants was security to humans, followed by crop damage and lastly mortality to elephants. The leading hotspots in prevalence of elephant threats to human security in decreasing order were; MailiTatu, Olmapinu, Metepes, and Enchurai. However, the severity of the threats in these areas could not be deduced due to insufficient records on the number of of elephant involved. For prevalence of crop destruction, the leading hotspots were (in decreasing order); Esukuta, Gichea farm, MailiTatu and Elerai. Two elephant mortalities were recorded at Lormanie and Olgirra with all the tusks removed.

From the Amboseli N. Park records, the leading elephant threat type was; farm invasion followed by crop damage, insecurity to humans and the least was destruction of property. In terms of prevalence of threats to farm invasion, the leading hotspots were (in decreasing order); Empironi, Sompet, Bondeni, Entonet, Kimana and Oloitoktok airstrip area; while the severity hotspots due to number of elephants involved (in decreasing order) were; Empiron, Sompet, Elerai, Bondeni and Kimana. For crop destruction prevalence, the leading hotspots were (in decreasing order); Sompet, Kimana and Bondeni; while for number of elephants involved (in decreasing order) were; Sompet, Bondeni, and Kimana. Threats to human security were recorded in only two places: 
Lemon'go in the former Kimana Group Ranch and Olgulului public camp site, with more elephants recorded for Lemon'go. One case of property destruction was recorded at Meshenani gate.

\subsection{Opinions of Key Informants and Experts and Researchers}

Overall, opinions of respondents identified four major aspects involving human-elephant interactions: 1) threats elephants pose to people; 2) threats people pose to elephants; 3) drivers of human-elephant conflicts and 4) critical resources which trigger conflicts between humans and elephants (Table 3(a) and Table 3(b)). The highest score for the severity scores was the increasing effects of the driving factors that fuel the human-elephant conflicts $(7.21 \pm 0.17)$ followed by severity for competition for critical resources between elephants and people (7.09 \pm 0.18$)$, threats elephants pose to people $(6.809 \pm 0.18)$ and lastly threats that people pose to elephants (6.50 \pm 0.22$)$. According to the key informants, overall, threats that elephants pose to people were more prevalent with a mean score of $5.28 \pm 0.18$ compared to threats people pose to elephants in the Amboseli area.

The key informants also identified five threats people pose to elephants and their habitats (Table 4). The most commonly mentioned threats (in decreasing order for both prevalence and severity) were poaching of elephants, followed by retaliatory killings, competition for critical resources, blocking of migration and dispersal routes, and harassment of elephants by the locals respectively. Of those who mentioned each of the threats, the highest prevalent score was given to competition for critical resources with a mean score of $6.32 \pm 0.44$ followed by blocking of migration and dispersal routes ( $6.24 \pm 0.46)$, harassment of elephants (4.83 \pm 0.75$)$, poaching (4.57 \pm 0.37 ), and lastly retaliatory killings ( $3.78 \pm 0.31$ ) (Table 5). Regarding the severity of the threats, the highest score was given for blocking of migration and dispersal routes with a mean score of $7.10 \pm 0.46$ followed by poaching $(6.85 \pm 0.38)$, competition for critical resources (6.65 \pm 0.43$)$, retaliatory killings $(6.06 \pm 0.40)$ and lastly harassment of elephants $(4.83 \pm 0.81$ ) by communities (Table 4). There were significant differences between some of the average scores on prevalence of threats $(\mathrm{F}=5.51 \mathrm{df}=4.174, \mathrm{p}<0.001)$. Specifically, the differences were between poaching and habitat destruction, retaliatory killing and habitat destruction, and between retaliatory killing and blocking of immigration routes. However, there was no significant difference among the average severity scores for threats people pose to elephants $(F=2.09, \mathrm{df}=3.174, \mathrm{p}=0.084)$.

A total of six threats elephants pose to people in the Amboseli area were also identified (Table 5). The most commonly mentioned threat (in decreasing order for both prevalence and severity) were; crop raiding, injury and

Table 3. (a) Overall prevalence and severity of various aspects of human-elephant conflicts in the Amboseli area; (b) Overall prevalence and severity of various aspects of human-elephant conflicts in the Amboseli area.

(a)

\begin{tabular}{|c|c|c|c|c|c|c|}
\hline \multirow{2}{*}{ Threats } & \multicolumn{3}{|c|}{ Prevalence of the threat type } & \multicolumn{3}{|c|}{ Severity of the threat type } \\
\hline & Number & Mean \pm SE & Distribution (\%) & Number & Mean \pm SE & Distribution (\%) \\
\hline $\begin{array}{l}\text { Threats elephants } \\
\text { pose to people }\end{array}$ & 264 & $5.28 \pm 0.18$ & $\begin{array}{c}\text { Low: } 31.4 \% \\
\text { Medium: } 39.8 \% \\
\text { High: } 28.8 \%\end{array}$ & 259 & $6.80 \pm 0.18$ & $\begin{array}{c}\text { Low: } 20.8 \% \\
\text { Medium: } 24.4 \% \\
\text { High: } 54.8 \%\end{array}$ \\
\hline $\begin{array}{l}\text { Threats people } \\
\text { pose to elephant }\end{array}$ & 216 & $4.80 \pm 0.21$ & $\begin{array}{c}\text { Low: } 40.2 \% \\
\text { Medium: } 38.0 \% \\
\text { High: } 21.8 \%\end{array}$ & 216 & $6.50 \pm 0.22$ & $\begin{array}{c}\text { Low: } 20.7 \% \\
\text { Medium: } 28.5 \% \\
\text { High: } 50.8 \%\end{array}$ \\
\hline
\end{tabular}

Low: scores of 1 - 3; Moderate: scores of 4 to 7; and High: scores of 8 to 10 .

(b)

\begin{tabular}{|c|c|c|c|}
\hline Threat to elephants & Number & Mean (Mean \pm SE) & Distribution (\%) \\
\hline Drivers of human-elephant conflicts & 206 & $7.21 \pm 0.17$ & $\begin{array}{c}\text { Low: } 9.7 \% \\
\text { Medium: } 34.5 \% \\
\text { High: } 55.8 \%\end{array}$ \\
\hline $\begin{array}{l}\text { Critical resource competed for between } \\
\text { elephants and people }\end{array}$ & 184 & $7.09 \pm 0.18$ & $\begin{array}{c}\text { Low: } 7.6 \% \\
\text { Medium: } 40.8 \% \\
\text { High: } 51.6 \%\end{array}$ \\
\hline
\end{tabular}

Low: scores of 1 - 3; Moderate: scores of 4 to 7; and High: scores of 8 to 10 . 
Table 4. Threats people pose to elephants in the Amboseli Ecosyste as scored by key informants on a scale of one to ten.

\begin{tabular}{|c|c|c|c|c|c|c|}
\hline \multirow{2}{*}{ Threats } & \multicolumn{3}{|c|}{ Prevalence } & \multicolumn{3}{|c|}{ Severity } \\
\hline & Number & Mean \pm SE & Distribution of (\%) & Number & Mean \pm SE & Distribution (\%) \\
\hline Poaching of elephants & 67 & $4.57 \pm 0.37$ & $\begin{array}{c}\text { Low: } 46.3 \% \\
\text { Medium: } 32.8 \% \\
\text { High: } 20.9 \%\end{array}$ & 67 & $6.85 \pm 0.38$ & $\begin{array}{c}\text { Low: } 22.4 \% \\
\text { Medium: } 14.9 \% \\
\text { High: } 62.7 \%\end{array}$ \\
\hline $\begin{array}{l}\text { Retaliatory killing } \\
\text { of elephants }\end{array}$ & 54 & $3.78 \pm 0.31$ & $\begin{array}{c}\text { Low: } 57.4 \% \\
\text { Medium: } 31.5 \% \\
\text { High: } 11.1 \%\end{array}$ & 53 & $6.06 \pm 0.40$ & $\begin{array}{c}\text { Low: } 24.5 \% \\
\text { Medium: } 34.0 \% \\
\text { High: } 41.5 \%\end{array}$ \\
\hline $\begin{array}{l}\text { Harassment of } \\
\text { elephants }\end{array}$ & 12 & $4.83 \pm 0.75$ & $\begin{array}{c}\text { Low: } 33.3 \% \\
\text { Medium: } 50 \% \\
\text { High: } 16.7 \%\end{array}$ & 12 & $4.83 \pm 0.81$ & $\begin{array}{c}\text { Low: } 33.3 \% \\
\text { Medium: } 50.0 \% \\
\text { High: } 16.7 \%\end{array}$ \\
\hline $\begin{array}{l}\text { Competition for } \\
\text { resources }\end{array}$ & 31 & $6.32 \pm 0.44$ & $\begin{array}{c}\text { Low: } 16.1 \% \\
\text { Medium: } 48.4 \% \\
\text { High: } 35.5 \%\end{array}$ & 31 & $6.65 \pm 0.43$ & $\begin{array}{c}\text { Low: } 9.7 \% \\
\text { Medium: } 45.1 \% \\
\text { High: } 45.2 \%\end{array}$ \\
\hline $\begin{array}{c}\text { Blocking of } \\
\text { migration routes }\end{array}$ & 21 & $6.24 \pm 0.46$ & $\begin{array}{c}\text { Low: } 9.5 \% \\
\text { Medium: } 61.9 \% \\
\text { High: } 28.6 \%\end{array}$ & 21 & $7.10 \pm 0.46$ & $\begin{array}{c}\text { Low: } 9.5 \% \\
\text { Medium: } 38.1 \% \\
\text { High: } 52.4 \%\end{array}$ \\
\hline
\end{tabular}

Low: scores of 1 - 3; Moderate: scores of 4 to 7; and High: scores of 8 to 10.

Table 5. Threats elephants pose to people in the Amboseli Ecosystem as scored by key informants on a scale of one to ten.

\begin{tabular}{|c|c|c|c|c|c|c|}
\hline \multirow{2}{*}{ Threat to people } & \multicolumn{3}{|c|}{ Prevalence of the threat type } & \multicolumn{3}{|c|}{ Severity of the threat type } \\
\hline & Number & Mean \pm SE & Distribution (\%) & Number & Mean \pm SE & Distribution (\%) \\
\hline Crop raiding & 73 & $6.95 \pm 0.26$ & $\begin{array}{c}\text { Low: } 4.1 \% \\
\text { Medium: } 46.6 \% \\
\text { High: } 49.3 \%\end{array}$ & 72 & $7.90 \pm 0.24$ & $\begin{array}{c}\text { Low: } 8.3 \% \\
\text { Medium: } 22.3 \% \\
\text { High: } 69.4 \%\end{array}$ \\
\hline Property destruction & 38 & $5.16 \pm 0.41$ & $\begin{array}{c}\text { Low: } 23.7 \% \\
\text { Medium: } 60.5 \% \\
\text { High: } 15.8 \%\end{array}$ & 36 & $5.78 \pm 0.49$ & $\begin{array}{c}\text { Low: } 30.6 \% \\
\text { Medium: } 30.5 \% \\
\text { High: } 38.9 \%\end{array}$ \\
\hline $\begin{array}{c}\text { Environmental } \\
\text { degradation and } \\
\text { destruction }\end{array}$ & 38 & $6.71 \pm 0.46$ & $\begin{array}{c}\text { Low: } 15.8 \% \\
\text { Medium: } 36.8 \% \\
\text { High: } 47.4 \%\end{array}$ & 38 & $6.89 \pm 0.43$ & $\begin{array}{c}\text { Low: } 13.2 \% \\
\text { Medium: } 28.9 \% \\
\text { High: } 57.9 \%\end{array}$ \\
\hline $\begin{array}{l}\text { General insecurity to } \\
\text { human life }\end{array}$ & 21 & $5.76 \pm 0.65$ & $\begin{array}{c}\text { Low: } 28.6 \% \\
\text { Medium: } 38.1 \% \\
\text { High: } 33.3 \%\end{array}$ & 21 & $5.62 \pm 0.64$ & $\begin{array}{c}\text { Low: } 38.1 \% \\
\text { Medium: } 38.1 \% \\
\text { High: } 23.8 \%\end{array}$ \\
\hline $\begin{array}{l}\text { Injury and death to } \\
\text { livestock }\end{array}$ & 37 & $3.78 \pm 0.37$ & $\begin{array}{c}\text { Low: } 51.4 \% \\
\text { Medium: } 40.5 \% \\
\text { High: } 8.1 \%\end{array}$ & 36 & $6.36 \pm 0.50$ & $\begin{array}{c}\text { Low: } 22.2 \% \\
\text { Medium: } 30.6 \% \\
\text { High: } 47.2 \%\end{array}$ \\
\hline $\begin{array}{l}\text { Injury and death to } \\
\text { human beings }\end{array}$ & 58 & $2.71 \pm 0.27$ & $\begin{array}{c}\text { Low: } 74.1 \% \\
\text { Medium: } 20.7 \% \\
\text { High: } 5.2 \%\end{array}$ & 58 & $0.72 \pm 0.44$ & $\begin{array}{c}\text { Low: } 27.6 \% \\
\text { Medium: } 15.5 \% \\
\text { High: } 56.9 \%\end{array}$ \\
\hline
\end{tabular}

Low: scores of 1 - 3; Moderate: scores of 4 to 7; and High: scores of 8 to 10.

or death to people, property destruction, environmental degradation and destruction, injury and death to livestock, and general insecurity to the local people. Of those who mentioned each of the threats, the highest prevalent score was given to crop raiding with a mean score of $6.95 \pm 0.26$ followed by environmental destruction and degradation (6.71 \pm 0.46$)$, general insecurity to humans (5.76 \pm 0.65$)$, property destruction (5.16 \pm 0.41$)$, injury and death to livestock (3.78 \pm 0.37$)$, and lastly injury and death to locals $(2.71 \pm 0.27)$ (Table 6). For severity of the threats, the highest score was given crop raiding with a mean score of $7.90 \pm 0.24$ followed environmental destruction and degradation (6.89 \pm 0.43$)$, injury and death to people (6.72 \pm 0.44$)$, injury and death to livestock (6.36 \pm 0.50$)$, property destruction (5.78 \pm 0.49$)$, general insecurity to people (5.62 \pm 0.64$)$ (Table 5). 
Table 6. Drivers for human-elephant conflicts as scored by key informants on a scale of one to ten.

\begin{tabular}{|c|c|c|c|}
\hline Driving factor & Responses & Mean \pm SE & Distribution of responses (\%) \\
\hline Elephant over-population & 11 & $7.55 \pm 0.81$ & $\begin{array}{c}\text { Low: } 9.1 \% \\
\text { Medium: } 45.4 \% \\
\text { High: } 45.5 \%\end{array}$ \\
\hline Unemployment and poverty & 36 & $7.53 \pm 0.33$ & $\begin{array}{c}\text { Low: } 5.6 \% \\
\text { Medium: } 33.3 \% \\
\text { High: } 61.1 \%\end{array}$ \\
\hline $\begin{array}{l}\text { Human encroachment on } \\
\text { elephant habitat }\end{array}$ & 24 & $7.58 \pm 0.54$ & $\begin{array}{l}\text { Low: } 8.3 \% \\
\text { Medium: } 33.4 \% \\
\text { High: } 58.3 \%\end{array}$ \\
\hline Drought and climate change & 44 & $6.80 \pm 0.37$ & $\begin{array}{c}\text { Low: } 11.4 \% \\
\text { Medium: } 43.1 \% \\
\text { High: } 45.5 \%\end{array}$ \\
\hline Increasing human population & 15 & $7.67 \pm 0.43$ & $\begin{array}{c}\text { Low: } 0 \% \\
\text { Medium: } 33.3 \% \\
\text { High: } 66.7 \%\end{array}$ \\
\hline Lucrative black market for ivory & 29 & $6.07 \pm 0.59$ & $\begin{array}{l}\text { Low: } 24.1 \% \\
\text { Medium: } 34.5 \% \\
\text { High: } 41.4 \%\end{array}$ \\
\hline $\begin{array}{l}\text { Blocking of elephant } \\
\text { immigration routes }\end{array}$ & 9 & $6.56 \pm 0.87$ & $\begin{array}{c}\text { Low: } 11.1 \% \\
\text { Medium: } 44.5 \% \\
\text { High: } 44.4 \%\end{array}$ \\
\hline $\begin{array}{l}\text { Lack of economic incentives to } \\
\text { people and poor policies }\end{array}$ & 27 & $8.19 \pm 0.39$ & $\begin{array}{l}\text { Low: } 7.4 \% \\
\text { Medium: } 7.4 \% \\
\text { High: } 85.2 \%\end{array}$ \\
\hline $\begin{array}{l}\text { Habituation of elephants to } \\
\text { humans and farms }\end{array}$ & 13 & $7.85 \pm 0.45$ & $\begin{array}{c}\text { Low: } 0 \% \\
\text { Medium: } 53.8 \% \\
\text { High: } 46.2 \%\end{array}$ \\
\hline
\end{tabular}

Low: scores of 1 - 3; Moderate: scores of 4 to 7; and High: scores of 8 to 10 .

There were differences in the average prevalence of threat types that elephants pose to people $(\mathrm{F}=25.51 \mathrm{df}=$ 5.258, $\mathrm{p}<0.001)$. Specifically, there were significant differences between prevalence scores for crop damage and property damage, crop damage and killing and injuring livestock, property damage and environmental destruction, environmental destruction, killing and injuring people, and between human insecurity, killing and injuring people. In regard to the severity of the threats elephants posed to humans, there were significant differences among some average scores $(\mathrm{F}=4.63, \mathrm{df}=5.258, \mathrm{p}<0.001)$, specifically between crop and property damage, and between crop damage and human insecurity.

Nine drivers fuelling human-elephant conflicts in Amboseli area emerged based on the opinions of the key informants (Table 6). The most commonly mentioned was; drought and climate change followed by unemployment and poverty, availability of black market for ivory, lack of economic incentives and enabling policies to the community, human encroachment on elephant habitat, increasing human population , habituation of elephants to farms and people, increasing elephant population, and blocking of elephant migration and dispersal routes. Of those who mentioned each of the drivers, the driver with the highest score was lack of economic incentives and enabling policies for the community with a mean score of $8.19 \pm 0.39$ followed by habituation of elephants to farms and people (7.85 \pm 0.45$)$, increasing human population (7.67 \pm 0.43$)$, human encroachment on elephant habitat $(7.58 \pm 0.54)$, increasing elephant population in the area $(7.55 \pm 0.81)$, unemployment and poverty among the people in the area $(7.53 \pm 0.33)$, drought and climate change $(6.80 \pm 0.37)$, blocking of elephant immigration and dispersal routes (6.56 \pm 0.87$)$, and lucrative black market for ivory (6.07 \pm 0.59$)$ respectively (Table 6). However, there were no significant differences between the average scores for the drivers that were mentioned by the key informants $(\mathrm{F}=1.44, \mathrm{df}=8.197, \mathrm{p}=0.18)$.

Only four critical resources competed for between elephants and people in the Amboseli region were identi- 
fied (Table 7). The most commonly mentioned was water resources followed by pasture, living space and woody plant resources. Of those who mentioned each of these critical resources, the leading resource competition was for living space with a mean score of $7.86 \pm 0.33$ followed by water resources $(7.15 \pm 0.29)$, pasture (7.00 \pm 0.33 ), and woody plant vegetation $(6.17 \pm 0.52)$ respectively (Table 7). Overall, there were no significant differences in the average scores among the critical resources competed for between elephants and the locals $(\mathrm{F}=$ 1.59 , df $=3.180, \mathrm{p}=0.194)$.

\section{Discussions}

\subsection{Field Records from KWS PAC Units}

It is very clear from field incidences that most of the human-conflicts in Amboseli region is about crop raiding. Elephants often gather closer to farms and thereby become a threat especially when the crops are ripe. Most of the recorded activities by the Kenya Wildlife Service (KWS) Problem Animal Units (PAC) were mainly on preventing crop damage as well as dealing with elephant conflicts compared other incidences of human-wildlife conflicts. Nevertheless, it was evident that not all incidences were reported or recorded consistently, and this is an issue that KWS management needs to address to streamline and strengthen their information gathering. This was particularly noted for the Rombo unit where valuable information (such as elephant retaliatory killing or poaching) that would aid in understanding and establishing mitigation strategies are not collected because of poor recording and archiving of reported elephant incidences.

Another incidence of human-elephant conflicts that was common was human injury and death. Although these incidences were few from records obtained, due to their sensitivity, one incidence can be one too many. Death and injury of people elicits stronger and lasting resentment against elephants and wildlife in general because of human social ties and support system. When human injury and death acts in combination to create fear and insecurity, a few cases would erode any positive interactions or benefits local people derive from elephants and wildlife conservation. People therefore expect KWS staff to act promptly and on time when incidences that touch on human security and safety occur, and as they do this, they should show empathy. Local communities believe and allege that KWS officers normally respond instantly if an elephant is injured or poached but usually take long to deal with elephant threats to human life. This is a widespread perception that needs to be reversed if elephant conservation will be valued and supported by local communities.

Information from the field records also showed there was a shortage of KWS staff to adequately and promptly dealing with human-elephant conflicts, and those who were available were not only overwhelmed, but sometimes engaged in other organization errands that prevented them from dealing with fatal interactions between people and elephants. Thus, many farmers and herders were requesting KWS to provide them with thunder flushes and other items to scare away elephants themselves, and prevent damages and insecurity other than

Table 7. Critical resources that are competed for between elephants and local people in Amboseli as scored by key informants on a scale of one to ten.

\begin{tabular}{|c|c|c|c|}
\hline $\begin{array}{l}\text { Critical resource competed for } \\
\text { between elephants and people }\end{array}$ & Responses & Mean \pm SE & Distribution of responses (\%) \\
\hline Woody vegetation & 18 & $6.17 \pm 0.52$ & $\begin{array}{c}\text { Low: } 5.6 \% \\
\text { Medium: } 66.60 \% \\
\text { High: } 27.80 \%\end{array}$ \\
\hline Water & 73 & $7.15 \pm 0.29$ & $\begin{array}{c}\text { Low: } 6.8 \% \\
\text { Medium: } 37.0 \% \\
\text { High: } 56.2 \%\end{array}$ \\
\hline Pasture & 59 & $7.00 \pm 0.33$ & $\begin{array}{c}\text { Low: } 11.9 \% \\
\text { Medium: } 38.9 \% \\
\text { High: } 49.2 \%\end{array}$ \\
\hline Space & 35 & $7.86 \pm 0.33$ & $\begin{array}{c}\text { Low: } 0 \% \\
\text { Medium: } 40.0 \% \\
\text { High: } 60.0 \%\end{array}$ \\
\hline
\end{tabular}

Low: scores of 1 - 3; Moderate: scores of 4 to 7; and High: scores of 8 to 10 . 
relying on KWS officers. However, mitigation strategies against elephants documented in literature includes promoting appropriate land uses near protected areas, farming non-suitable crops for raiding (e.g. chilies), enhanced security for the people and elephants, strategic vigilance by farmers, enhancing benefits to landowners, involving communities in elephant conservation, expanding range for elephants by merging land to form more space for elephants which benefit the landowners in ecotourism investments, helping local community bear the cost of conservation and reducing losses due elephants through leasing land [29]-[31].

Field data from KWS-PAC records also revealed hotspots where crop raiding, insecurity to people, destruction of property and elephant poaching were most prevalent. Higher cases of prevalence and severity of conflicts seemed to occur in; Sompet, Bondeni, Impironi, Sayianka, InkariakaRongena, Elerai, Noomanayiat, Kimana, Lemon'go and Entonet for cases reported to Amboseli N. Park and Oloitoktok PAC offices. Most of these were on farm raiding which led to crop damage and property destruction. For the Rombo area, the leading hotspots for prevalence and severity of human-elephant conflicts were; MailiTatu, Olmapinu, Metepes, Enchurai, Esukuta, Gichea farm. These areas need more KWS PAC personnel and engagement with the community on adoption of other human-elephant mitigation strategies. Awareness of other strategies, discussion with farmers on how to improve their own vigilance and better support from KWS will reduce pressure on PAC personnel and also empower the communities who farm with elephant-friendly mitigation strategies against crop raiding [18]. Collaboration of farmers in vigilance against crop raiding by elephants especially at night and wet season (when incidences seem high) will be critical, as well as monitoring of success of adopted mitigation strategies and support of KWS is important as a way forward.

The field records showed two (2) cases of elephant mortality which involved loss of their tusks as well. Since no detailed information was recorded, it was significant finding as it suggests incidences of retaliation against elephants by the community or even poaching. With loss of tusks, it further suggests a commercial motivation to killing of elephants, especially in Rombo region, specifically at Lormanie and Olgirra. It should be noted that poaching has been a leading cause of the decline of elephants throughout their range in Africa. In Kenya particularly, there has been increased vigilance and anti-poaching patrols by KWS that has been largely successful and reduced and or contained the numbers of poached elephants. However in recent times, there has been a surge of poaching in both the Tsavo and Amboseli areas. Several factors such as insufficient personnel, inadequate patrols, renewed activities on in international black markets in ivory trade, and demand of ivory products in Asia and Far East have increased poaching reward and proved a challenge to elephant protection in East Africa. A detailed forensic analysis of the causes for the increase of elephant poaching and retaliatory killing and be addressed by the KWS.

\subsection{Opinions of Key Informant and Local Leadership and Researchers}

Key informants working in elephant research, conservation, KWS elephant program senior staff and local leadership all identified four critical thematic areas that influence and affect human-elephant conflicts in the Amboseli area: elephants pose threats to human interests, elephants pose threats to human interests, there are underlying drivers to this conflict, and it all revolves around access and availability of critical resources. Threats to elephants by people and to people by elephants were scored for prevalence and severity. From overall scores, it was established that among the key thematic issues that define human-elephant conflicts, higher average scores were indicated for drivers of the conflicts compared to the conflicts themselves. This implies that many people are aware of the courses of conflicts, which must be addressed and if they are, it will solve the consequences that manifest themselves in humans hurting elephant interests and elephants hurting human interests.

It was however noteworthy that competition for critical resources was ranked second highest, still alluding to the importance of causal factors of conflicts rather than actual direct conflicts themselves. Therefore there is need to address the driving factors (both elephant-related and human related) and reduce competition for critical resources by expanding elephant range and tolerance for elephants by the people. But this is only possible if costs to people by elephants can be offset by stakeholders and also compensating people for the resources shared or having a benefit framework for elephant use of landowners' private land. According to the views of the key informants, the threats that elephants pose to the people ranked high in severity than threats people pose to elephants. It therefore implies that any conservation action should have a human socio-economic dimension and not only focus on elephant welfare, but that of the local community who bear the cost of elephant conservation.

Most key informants identified poaching, retaliatory killings, competition for critical resources, blocking of 
immigration and dispersal routes by changing land uses, and elephant harassment respectively as key threats people pose to elephants in the Amboseli region. Of these, the order of the most prevalence was; competition for critical resources, blocking of immigration and dispersal routes, harassment of elephants, poaching and retaliatory killing. These identified threats are the most common and comprehensive from observations on the ground and compared from similar studies in literature, [5] [19] [32] [33]. However, when it comes to scoring, it is likely that it will reflect true prevalence or will have a bias to what affects people most or what is in the most interest of the scorers. It also depends on the position and profession of the scorer. People in conservation will score highly effects to elephants while those in community leadership will score highly effects of elephants to people. Nevertheless poaching and elephant harassment by the people is actually of low compared to competition for critical resources, blocking of elephant immigration and dispersal routes by changing land uses, and elephant raiding crops.

Encroachment on elephant habitats that lead to blocking immigration routes, poaching and competition for critical resources are increasing in the Amboseli Ecosystem. This is exacerbated by the impacts and effects of climate change that is making the area hotter and drier and therefore affecting abundance and availability of critical resources such as water, pasture, woody plant resources and general space by both elephants and people. The severity of these threats to elephants are likely to continue and now threaten the positive steps in Kenya and East Africa made to reduce elephant mortality and increase viable populations in natural range. The combination of poaching, retaliatory killing, shrinking of dispersal space together present threaten a thriving viable elephant population in the area. Increasing temperature due to climate change will increase infant elephant morality, heat strokes in elephants; massive death is frequent droughts, vulnerable to diseases and pathogens that will compromise their health and body condition [34].

Threats that elephants pose to people included crop raiding, injury and death to people, destruction of other (non-crop) property, environmental destruction and degradation, injury and death to livestock, and general insecurity to people. It is interesting that key informants gave the highest score of prevalence to environmental destruction and degradation. This may be tied close to the competition for critical resources with the people given that the local community is generally poor and livelihood options limited and so resources such as pasture, plant resources, woody plants and water are so important to their livelihood and so negative impacts to elephants elicits strong negative reaction from the community. Followed by this is the issue of general insecurity elephants pose which affects economic activities, daily lives, schooling and other important social and economic activities. Despite injury and death to livestock and people ranking lower on prevalence scales, when they do happen, they have a stronger and lasting negative reaction from the community against the elephants because of the value of human life and socio-economic and cultural role of livestock.

On severity scoring, the patterns were similar to the records reported from the field incidences, with crop raiding leading the severity of negative impacts of elephants to the local community. With an increasing farming community and land use, conflicts related to crop raiding will continue to escalate and to lead in both prevalence and severity in the Amboseli area. Second in severity is environmental destruction and degradation, which is a critical aspect tied to competition for space and critical resources which people derive from the environment and with the high and relatively wasteful resource (water, pasture, plant resources), their impacts on the environment affects the abundance and availability of these resources needed by the local community for construction, livestock food, herbal medicine, housing, shelter, firewood among other local uses and needs [35]. Elephants in high population numbers and in insularized ecosystems have been reported to have negative impacts to habitats and vegetation [36]-[43]. An effect of a few elephants create a big impact that give the impression among local communities that elephant numbers are increasing or that there is a general over-population of elephant numbers when it may simply be a function of elephant range compression and body size impacts on environment [15] [44].

Key informants identified nine drivers that fuel human-elephant conflicts, generally ranging from; increasing human population, lack of economic incentives from conservation and increased cost of elephant conservation to local community, to lack of socio-economic opportunities and impacts of climate change. In terms of scoring on prevalence, the leading driver was rightly lack of economic incentives and benefits to the local people from elephant and generally wildlife conservation in the area. This should be viewed in the context of the poverty in the area and the uncompensated impacts of elephants that increase and entrench poverty and increase costs to local community from conservation of elephants and wildlife in general.

It is important for the government, KWS and conservation agencies to deal with the fact that a poor commu- 
nity receiving impacts from elephants and bearing the cost of conservation without economic compensation, incentives or support will be negative to elephants and generally conservation. This must be prioritized in conservation psyche especially for the Amboseli region because most of the wildlife occur on private community land and spend only a dry season inside Amboseli N. Park. The challenge is however as human population in the area increases from high birth rate and from immigration, and as land uses changes from predominantly pastoralism to agro-pastoralism and agriculture. Competition for critical resources (such as space/land, water, pasture and woody plant resources) and conflicts are likely to escalate rather than diminish.

An interesting driver that was identified by key informants (possibly because it has a long term effect rather than immediate short term effects) was climate. This is a zero sum effect that complicates all planning and strategies of humanity whether in economic planning, conservation strategies, social mapping and forecasting of people's needs, prediction of risk and emergency areas in nations of global scene. With a generally reported increase by one degree globally, animal habitats are likely to be drier and hotter [34]. Species response is likely to increase their range as they search for phonologically changing forage and prey base, as well as changes in abundance and availability of critical resources. Effects on population dynamics are likely to decreased fecundity, survival and body condition and increased mortality and reduced population growth. For elephants, predictions are likely changes in habitat and space use, more ranging and competition for critical resources. Since local people will also be responding to this phenomenon, predictions for more persistence and intense human-conflicts are envisaged.

Climate change is of great concern in the Amboseli region because it is a semi-arid area whose water resources mainly come from melting snow and rainfall on Mt. Kilimanjaro system. However, with snow and glacier cover greatly diminishing on the mountain because of climate change [45], the Amboseli N. Park's swamps are likely to reduce significantly, putting pressure on other water resources used by communities and livestock outside the park. Elephant range use is limited by forage and water, and without these critical resources, their population will decline. But since they are long-ranging species, the search will be intense for these resources and therefore conflicts with human and livestock competitors are likely to escalate as both man and beast adapt to climate change. This effect of climate change is likely to have a compounding effect of both impacts of elephants to people, effects of people on elephants and increases the effects of drivers to this conflict.

\section{Conclusions}

Key insights have been obtained from this study that will help KWS Elephant Program plan and manage conflicts and elephant conservation in the Amboseli ecosystem. We recommend that KWS PAC personnel people should be trained on simple and consistent entry of field incidences in elephant-human conflicts because they form important data for understanding prevalence and severity of conflicts and hotspots for these. Further, KWS should deploy enough personnel in PAC units in Rombo, Oloitoktok and Park headquarters and they should not do other errands other than dealing with human-wildlife conflicts control. Information showed that in some situations, KWS PAC did not take any action on reported cases because they were on other assignments or engaged elsewhere. This will remove the impression that they respond when elephants are harmed by people, and not when elephants harm people or destroy their property

The newly enacted Wildlife (2013) Act should be quickly implemented so as to address the great costs that local people shoulder to conserve elephants by providing adequate and timely compensation to reported and verified cases to forestall the negative perceptions against elephants, and increase intolerance of locals to elephants and wildlife in general [46] so as to win more space for elephant dispersal outside the protected areas [47] [48]. Costs such as injury and death to people and livestock, crop raiding, destruction of property and general insecurity affect the economy and freedom of people and therefore entrench poverty and undermine their social rights. Compensation by the government to supplement consolation schemes given by some NGO's in the area, (and which are very popular with the local community) will help local community bear the cost of conservation.

Elephant-human conflict hotspots (areas with high prevalence and severity of conflicts) identified in this study should receive more protection from elephant damages, as well as elephants protected from persecution and retaliation such as poaching in some of the hotspots like Rombo. Further research should focus on mapping prevalence and severity of conflicts and risk assessment (to people from elephants, and elephants from people) so as to take a proactive action in controlling these damages and conflicts. Further studies on the effect of climate change will be on relationships between people [45] and the elephants which need to be investigated further. 


\section{Acknowledgements}

This work was done under a 5-year research collaboration on elephant ranging and space needs between IFAW, KWS and SFS. We therefore thank The International Fund for Animal Welfare (IFAW) for supporting this study, and The School for Field Studies (SFS) for providing field expertise and intellectual support to do this work. We thank our key collaborator and partner the Kenya Wildlife Service (KWS) particularly the Dr. Shadrack Ngene, Dr. Charles Musyoki, Mr. Richard Chepkwony, Mr. Stephen Ndambuki and all the rangers and wardens of PAC in Oloitoktok and Rombo. We thank the field assistants Arnest Lenkoina Manto, Daniel Moonka, Julius T. Kayiai, and Francis Nkadayo for assistance with data collection in the field. We thank all our key experts in AWF, ACC, KWS, LG, BL, community leaders, community opinion leaders and all others who helped us from Kuku, Kimana, Mbirikani, Olgulului/Ololorashi group ranches. We thank the anonymous referees who helped improve earlier manuscripts.

\section{References}

[1] Western, D. (1989) The Ecological Role of Elephants in Africa. Pachyderm, 12, 43-46.

[2] Yaw, O.-O. and Lonneke, B. (2008) Human-Wildlife Conflict: Elephant Technical Manual. Wildlife Management Working Paper, Lagos Nigeria.

[3] Esikuri, E.E. (1998) Spatio-Temporal Effects of Land Use Changes in a Savanna Wildlife Area of Kenya. Dissertation Submitted to the Faculty of the Virginia Polytechnic Institute and State University in Partial Fulfillment of the Requirements for the Degree of Doctor of Philosophy in Fisheries and Wildlife Sciences, Virginia, USA.

[4] Archie, E.A. and Chiyo, P.I. (2012) Elephantbehaviour and Conservation: Social Relationships, the Effects of Poaching, and Genetic Tools for Management. Molecular Ecology, 21, 765-778. http://dx.doi.org/10.1111/j.1365-294X.2011.05237.x

[5] Litoroh, M., Omondi, P., Kock, R. and Amin, R. (2012) Conservation and Management Strategy for the Elephants in Kenya. 2012-2021. The Kenya Wildlife Service (KWS), Nairobi.

[6] Okello, M.M., Seno, S.K. and Nthiga, R.W. (2009) Reconciling Peoples’ Livelihoods and Environmental Conservation in the Rural Landscapes in Kenya: Opportunities and Challenges in the Amboseli Landscapes. Natural Resources Forum, 33, 123-133. http://dx.doi.org/10.1111/j.1477-8947.2009.01216.x

[7] Okello, M.M., Buthmann, E., Mapinu, B. and Kahi, C. (2010) Community Opinions on Wildlife, Resource Use and Livelihood Competition in Kimana Group Ranch Near Amboseli, Kenya. The Open Conservation Biology Journal, 4, 34-45.

[8] Spinage, C.A. (1990) Botswana’s Problem Elephants. Pachyderm, 13, 14-19.

[9] Laws, R.M. and Parker, I.S.C. (1968) Recent Studies on Elephant Populations in East Africa. Symposium of the Zoological Society of London, 21, 319-359.

[10] Corfield, T.F. (1973) Elephant Mortality in Tsavo National Park, Kenya. East African Wildlife Journal, 11, $339-368$. http://dx.doi.org/10.1111/j.1365-2028.1973.tb00098.x

[11] Barnes, R.F.W., Barnes, K.L. and Kapela, E.B. (1994) he Long Term Impact of Elephant Browsing on Baobab Trees at Msembe, Ruaha National Park, Tanzania. African Journal of Ecology, 32, 177-184. http://dx.doi.org/10.1111/j.1365-2028.1994.tb00569.x

[12] Caughley, G. (1976) The Elephant Problem-An Alternative Hypothesis. East African Wildlife Journal, 14, $265-283$. http://dx.doi.org/10.1111/j.1365-2028.1976.tb00242.x

[13] Caughley, G. (1976) Plant-Herbivore Systems. In: May, R.M., Ed., Theoretical Ecology, Blackwell Scientific Publications, Oxford, 530 p.

[14] Bell, R.H.V. (1985) Elephants and Woodland—A Reply. Pachyderm, 5, 17-18.

[15] Van Aarde, R.J. and Jackson, T. (2006) How Many Is Too Many? Africa Geographic, 14, 36-38.

[16] Van Aarde, R.J. and Ferreira, S. (2009) Elephant Populations and Cites Trade Resolutions. Environmental Conservation, 36, 8-10. http://dx.doi.org/10.1017/S0376892909005438

[17] Okello, M.M. (2005) Land Use Changes and Human-Wildlife Conflicts in the Amboseli Area, Kenya. Human Dimensions of Wildlife, 10, 19-28. http://dx.doi.org/10.1080/10871200590904851

[18] Sitati, N., Walpole, M.J. and Leader-Williams, N. (2005) Factors Affecting the Susceptibility of the Farms to Crop Raiding by African Elephants: Using a Predictive Model to Mitigate Conflicts. Journal of Applied Ecology, 42, 11751182. http://dx.doi.org/10.1111/j.1365-2664.2005.01091.x

[19] Hoare, R.E. (1999) Determinants of Human Elephant Conflict in a Land-Use Mosaic. Journal of Applied Ecology, 36, 
689-700. http://dx.doi.org/10.1046/j.1365-2664.1999.00437.x

[20] Okello, M.M. (2009) Contraction of Wildlife Dispersal Area and Displacement by Humanactivities in Kimana Group Ranch Aear Amboseli National Park, Kenya. The Open Conservation Biology Journal, 3, 49-56.

[21] Okello, M.M. and Kioko, J.M. (2010) Contraction of Wildlife Dispersal Area in Olgulului-Ololorashi Group Ranch around Amboseli National Park, Kenya. The Open Conservation Biology Journal, 4, 34-45. http://dx.doi.org/10.2174/1874839201004010034

[22] Monney, A.K., Dakwa, K.B. and Wiafe, E.D. (2010) Assessment of Crop Raiding Situation by Elephants (Loxodontaafricanacyclotis) in Farms around Kakum Conservation Area, Ghana. International Journal of Biodiversity and Conservation, 2, 243-249.

[23] Chiyo, P.I., Lee, P.C., Moss, C.J., Archie, E.A., Hollister-Smith, J.A. and Alberts, S.C. (2011) No Risk, No Gain: Effects of Crop Raiding and Genetic Diversity on Body Size in Male Elephants. Behavioral Ecology, 22, 552-558. http://dx.doi.org/10.1093/beheco/arr016

[24] Kioko, J., Muruthi, P., Omondi, P. and Chiyo, P.I. (2008) The Performance of Electric Fences as Elephant Barriers in Amboseli, Kenya. South African Journal of Wildlife Research, 38, 52-58. http://dx.doi.org/10.3957/0379-4369-38.1.52

[25] Thouless, C.R. and Sakwa, J. (1995) Shocking Elephants: Fences and Crop Raiders in Laikipia District, Kenya. Biological Conservation, 72, 99-107. http://dx.doi.org/10.1016/0006-3207(94)00071-W

[26] Briggs, H.C., Slotow, R., Scholes, R.J., Carruthers, J., Van Aarde, R., Kerley, G.H.I., Twine, W., Grobler, D.G., Berthshinger, H. and Grant, C.C. (2008) Towards Integrated Decision Making for Elephant Management. In: Scholes, R.J. and Mennell, K.G., Eds., Elephant Management: A Scientific Assessment of South Africa, Wits University Press, Johannmesburg, 32-42.

[27] Kangwana, K. (1996) Studying Elephants. AWF Technical Series 7. The African Wildlife Foundation (AWF), Nairobi.

[28] Zar, J.H. (1999) Biostatistical Analysis. Fourth Edition, Prentice Hall, Inc., Upper Saddle River, 663 p.

[29] Erwin, H.B., Randall, B.B., Randy, S. and Philip, K.T. (2006) Wildlife Conservation in Amboseli, Kenya: Paying for Nonuse Values. Roles of Agriculture Project Environment Service, December 2006, Agricultural and Development Economics Division (ESA), Food and Agriculture Organization of the United Nations.

[30] Jackson, T.P., Mosojane, S., Ferreira, S.M. and Van Aarde, R.J. (2008) Solutions for Elephant Loxodonta africana Crop Raiding in Northern Botswana: Moving away from Symptomatic Approaches. Oryx, 42, 83-91. http://dx.doi.org/10.1017/S0030605308001117

[31] Leggett, K.E.A. (2006) Effect of Artificial Water Points on the Movement and Behaviour of Desert-Dwelling Elephants of North-Western Namibia. Pachyderm, 40, 24-34.

[32] Prinns, H.H.T. (1987) Nature Conservation as an Integral Part of Optimal Land Use in East Africa: The Case of the Masai Ecosystem of Northern Tanzania. Biological Conservation, 40, 141-161. http://dx.doi.org/10.1016/0006-3207(87)90064-4

[33] Okello, M.M. and Kiringe, J.W. (2004) Threats to Biodiversity and Their Implications in Protected and Adjacent Dispersal Areas of Kenya. Journal for Sustainable Tourism, 12, 55-69. http://dx.doi.org/10.1080/09669580408667224

[34] Kinahan, A.A., Pimm, S.L. and Van Aarde, R.J. (2007) Ambient Temperature as a Determinant of Landscape Use in the Savanna Elephant, Loxodonta africana. Journal of Thermal Biology, 32, 47-58. http://dx.doi.org/10.1016/j.jtherbio.2006.09.002

[35] Kiringe, J.W. and Okello, M.M. (2005) Use and Availability of Tree and Shrub Resources on Maasai Communal Rangelands near Amboseli, Kenya. African Journal of Range and Forage Science, 22, 37-45. http://dx.doi.org/10.2989/10220110509485860

[36] Gadd, M.E. (2002) The Impact of Elephants on the Marula Tree Sclerocarya birrea. African Journal of Ecology, 40, 328-336. http://dx.doi.org/10.1046/j.1365-2028.2002.00385.x

[37] Western, D. and Maitumo, D. (2004) Woodland Loss and Restoration in a Savanna Park: A 20-Year Experiment. African Journal of Ecology, 42, 111-121. http://dx.doi.org/10.1111/j.1365-2028.2004.00506.x

[38] Midgley, J.J., Balfour, D. and Kerley, G.I.H. (2005) Why Do Elephants Damage Savanna Trees? South African Journal of Science, 101, 213-215.

[39] De Beer, Y., Kilian, W., Versfeld, W. and Van Aarde, R.J. (2006) Elephants and Low Rainfall Alter Woody Vegetation in Etosha National Park, Namibia. Journal of Arid Environments, 64, 412-421. http://dx.doi.org/10.1016/j.jaridenv.2005.06.015

[40] Guldemond, R. and Van Aarde, R. (2007) The Impacts of Elephants on Plants and Their Community Variable in South Africa's Maputaland. African Journal of Ecology, 45, 327-335. http://dx.doi.org/10.1111/j.1365-2028.2007.00714.x

[41] Western, D. (2007) A Half Century of Habitat Change in Amboseli National Park, Kenya. African Journal of Ecology, 45, 302-310. http://dx.doi.org/10.1111/j.1365-2028.2006.00710.x 
[42] Western, D. (1975) Water Availability and Its Influence on the Structure and Dynamics of a Savanna Large Mammal Community. East African Wildlife Journal, 13, 265-286. http://dx.doi.org/10.1111/j.1365-2028.1975.tb00139.x

[43] Western, D., Rosemary, G. and Jeffrey, W. (2009) The Impact of Subdivision and Sedentarization of Pastoral Lands on Wildlife in an African Savanna Ecosystem. Biological Conservation, 142, 2538-2546. http://dx.doi.org/10.1016/j.biocon.2009.05.025

[44] Owen-Smith, R.N. (1988) Megaherbivores. The Influence of Very Large Body Size on Ecology. Cambridge University Press, Cambridge. http://dx.doi.org/10.1017/CBO9780511565441

[45] Mumby, H.S., Courtiol, A., Mar, K.U. and Lummaa, V. (2013) Climatic Variation and Age-Specific Survival in Asian Elephants from Myanmar. Ecology, 94, 1131-1141. http://dx.doi.org/10.1890/12-0834.1

[46] Bulte, E., Boone, R.B., Stringer, R. and Thornton, P.K. (2008) Elephants or Onions? Paying for Nature in Amboseli, Kenya. Environment and Development Economics, 13, 395-414.

[47] Okello, M.M. (2012) The Contraction of Wildlife Dispersal Areas by Human Structures and Activities in Mbirikani Group Ranch in the Amboseli Ecosystem, Kenya. International Journal of Biodiversity and Conservation, 4, $243-259$.

[48] Okello, M.M. and Kioko, J.K. (2010) Contraction of Wildlife Dispersal Area in Olgulului-Ololorashi Group Ranch around Amboseli National Park, Kenya. The Open Conservation Biology Journal, 4, 28-39. 
Scientific Research Publishing (SCIRP) is one of the largest Open Access journal publishers. It is currently publishing more than 200 open access, online, peer-reviewed journals covering a wide range of academic disciplines. SCIRP serves the worldwide academic communities and contributes to the progress and application of science with its publication.

Other selected journals from SCIRP are listed as below. Submit your manuscript to us via either submit@scirp.org or Online Submission Portal.
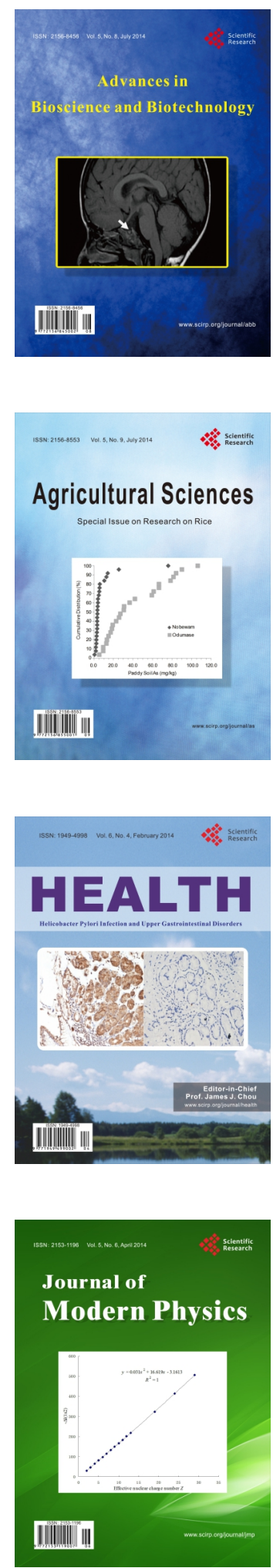
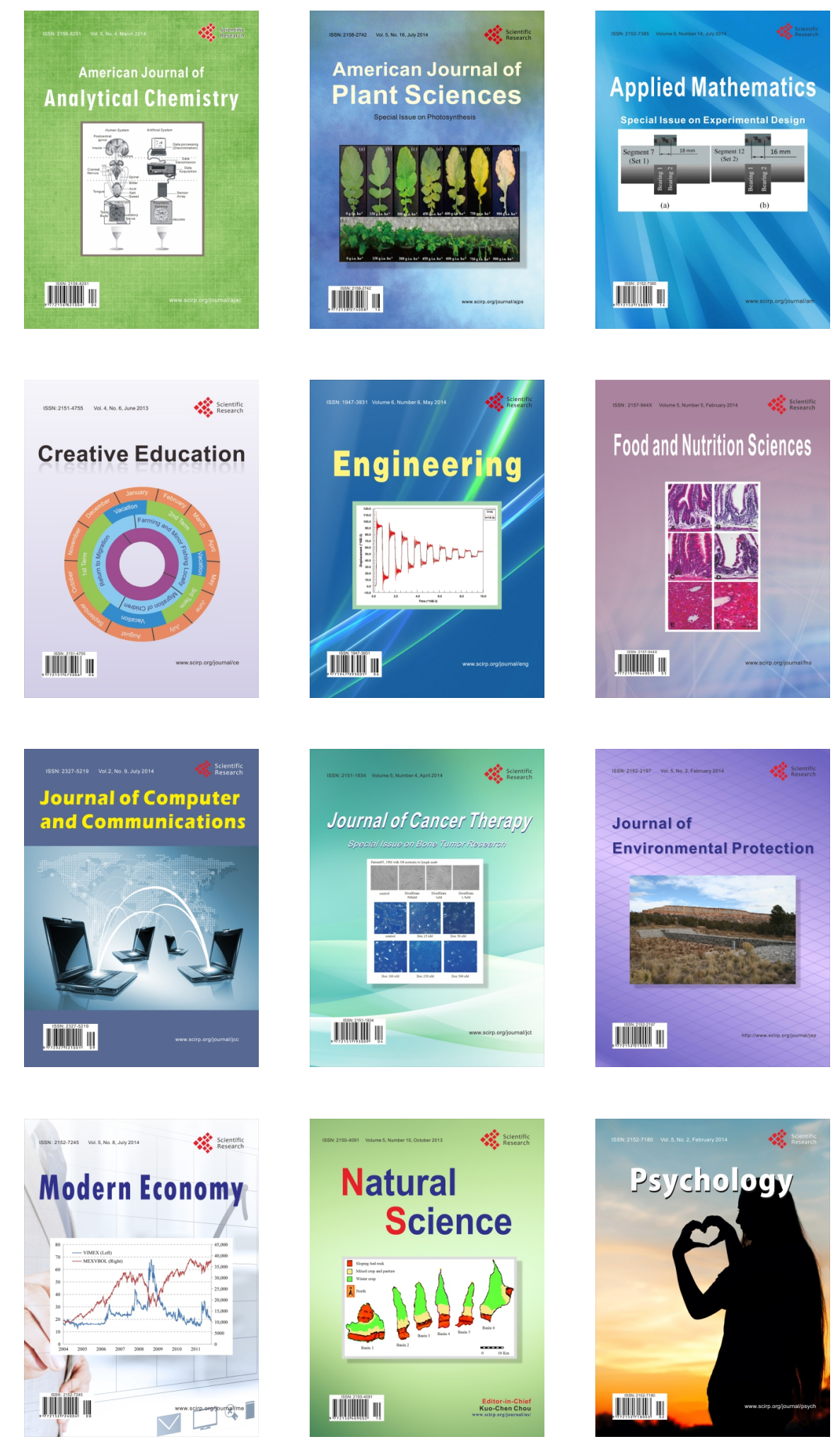